\title{
Pengaruh Thin Capitalization dan Transfer Pricing Aggressiveness terhadap Penghindaran Pajak dengan Financial Constraints sebagai Variabel Moderasi
}

\author{
Melina Fajrin Utami ${ }^{1}$, Ferry Irawan ${ }^{2 *}$ \\ Politeknik Keuangan Negara STAN, Politeknik Keuangan Negara STAN \\ melina.fajrin@gmail.com, ferry.irawan@pknstan.ac.id
}

*Corresponding Author

Diajukan : 22 Desember 2021

Disetujui : 30 Desember 2021

Dipublikasi : 1 Januari 2022

\section{ABSTRACT}

The purpose of this study was to determine the effect of thin capitalization, transfer pricing aggressiveness on tax avoidance with financial constraints as moderating variable. This study used a quantitative approach with population with sample of manufacturing companies listed on the Indonesia Stock Exchange from 2016 to 2019. The sampling technique used purposive sampling and obtained 72 companies as samples. This study used panel data and the analysis was multiple linear regression and interaction regression. The results show that thin capitalization, transfer pricing aggressiveness, and financial constraints have a positive effect on tax avoidance. Further research shows that financial constraints strengthen the effect of thin capitalization on tax avoidance, but financial constraints do not moderate the effect of transfer pricing aggressiveness on tax avoidance.

Keywords: financial constraints; tax avoidance; thin capitalization; transfer pricing aggressiveness;

\section{PENDAHULUAN}

Pajak memiliki peran penting dalam pembangunan nasional, mengingat fungsi utamanya sebagai penunjang penerimaan negara (budgetair). Pemerintah mengandalkan pajak dalam mendanai Anggaran Pendapatan dan Belanja Negara (APBN). Peran pajak di atas membuat pencapaian target penerimaan yang telah ditetapkan menjadi hal penting. Data target dan realisasi penerimaan pajak ditunjukkan dalam Tabel 1 berikut.

Tabel 1. Target dan Realisasi Penerimaan Pajak (Triliunan Rupiah)

\begin{tabular}{|c|r|r|r|r|r|r|r|r|}
\hline Tahun & 2012 & 2013 & 2014 & 2015 & 2016 & 2017 & 2018 & 2019 \\
\hline Target & 743.3 & 878.7 & $1,016.2$ & $1,148.4$ & $1,246.1$ & $1,489.3$ & $1,539.2$ & $1,472.7$ \\
\hline Realisasi & 723.3 & 873.9 & 980.5 & $1,077.3$ & $1,146.9$ & $1,240.4$ & $1,285.0$ & $1,343.5$ \\
\hline Capaian (\%) & 97.31 & 99.45 & 96.49 & 93.81 & 92.04 & 83.29 & 83.48 & 91.23 \\
\hline
\end{tabular}

Sumber: Diolah dari data Laporan Keuangan Pemerintah Pusat (2020)

Data pada Tabel 1 menunjukkan bahwa penerimaan pajak dari tahun ke tahun selalu meningkat, akan tetapi masih belum dapat mencapai target yang telah ditetapkan. Seiring dengan target penerimaan pajak yang tidak tercapai, tax ratio Indonesia bisa dikatakan stagnan berada di angka 10-12\% sejak tahun 2010 s.d. 2019. Tax ratio merupakan salah satu penilaian yang digunakan untuk melihat kemampuan pemerintah dalam mengumpulkan penerimaan pajaknya. 
Semakin besar penerimaan pajak suatu negara maka semakin tinggi tax ratio yang dimiliki (DPR, 2014).

Salah satu penyebab rendahnya tax ratio Indonesia adalah penghindaran pajak (OECD, 2020). Praktik penghindaran pajak yang masih sering terjadi juga ikut berpengaruh langsung pada penerimaan pajak serta tidak maksimalnya kinerja pemungutan pajak (Rosadi, 2019). Berdasarkan temuan yang diumumkan oleh Tax Justice Network, penghindaran pajak diestimasi merugikan negara hingga Rp 68,7 triliun per tahun.

Otoritas pajak seluruh dunia telah menyadari bahwa praktik penghindaran pajak dengan cara mengalihkan penghasilan ke luar negeri berkontribusi terhadap terkikisnya penerimaan pajak suatu negara. Terdapat beberapa praktik penghindaran pajak yang dapat dilakukan oleh perusahaan antara lain melalui thin capitalization, transfer pricing aggresiveness, income shifting, multinationality, dan tax haven utilization (Taylor \& Richardson, 2012). Lebih lanjut lagi diungkapkan bahwa thin capitalization dan transfer pricing merupakan pendorong utama praktik penghindaran pajak.

Thin capitalization digunakan dalam praktik penghindaran pajak karena bunga utang dapat menjadi pengurang penghasilan pajak (deductible expense). Oleh karena itu, perusahaan dapat memanfaatkan insentif berupa pengurangan pajak pada tarif yang lebih tinggi akibat adanya beban bunga. Melalui praktik transfer pricing, perusahaan dapat mengatur harga transfer untuk transaksi dengan pihak yang memiliki hubungan istimewa sehingga mendorong perusahaan melakukan pengalihan laba antar perusahaan tersebut dengan tujuan untuk meningkatkan pendapatan global melalui tindakan penghindaran pajak.

Penelitian atas hubungan thin capitalization terhadap penghindaran pajak telah ada sebelumnya dengan hasil kesimpulan berbeda. Penelitian yang dilakukan Taylor \& Richardson (2012); Falbo \& Firmansyah (2018); Nadhifah \& Arif (2020); Jumailah (2020) memberikan hasil bahwa thin capitalization mempunyai pengaruh positif terhadap penghindaran pajak. Hal ini berarti bahwa tindakan thin capitalization yang dilakukan perusahaan bertujuan untuk mengurangi pajak perusahaan. Andawiyah et al. (2019) dan Darma (2019) menyimpulkan bahwa thin capitalization memiliki pengaruh terhadap penghindaran pajak. Berbeda dengan penelitianpenelitian sebelumnya Selistiaweni et al. (2020); Nainggolan dan Sari (2019); Bandiyono dan Murwaningsari (2019) memberikan kesimpulan thin capitalization tidak memiliki pengaruh ke penghindaran pajak.

Faktor lain yang memengaruhi penghindaran pajak yaitu transfer pricing aggressiveness. Sebagian besar penelitian mengungkapkan bahwa transfer pricing telah menjadi skema penghindaran pajak utama yang dimanfaatkan perusahaan dalam memaksimalkan laba global dan meminimalkan pajak (Amidu et al., 2019). Eden \& Smith (2011) menyatakan transfer pricing aggressiveness adalah insentif pajak maupun keuangan yang didapat suatu perusahaan ketika menggunakan perbedaan keuangan, ekonomi serta wilayah yurisdiksi yang tidak sama. Manfaat itu diperoleh dengan adanya kesempatan dalam melakukan penghindaran pajak melalui transaksi antarpihak berelasi di wilayah yurisdiksi perpajakan berbeda (Desai \& Dharmapala, 2006).

Penelitian atas pengaruh transfer pricing terhadap penghindaran pajak telah dilakukan antara lain Taylor dan Richardson (2012) dan Amidu et al. (2019) dengan kesimpulan bahwa transfer pricing aggressiveness berpengaruh positif signifikan terhadap penghindaran pajak. Hal ini dapat diartikan bahwa tindakan transfer pricing aggressiveness dilakukan perusahaan dalam rangka memperkecil pajak. Semakin tinggi nilai transfer pricing aggressiveness maka semakin tinggi pula tingkat penghindaran pajak yang dilakukan perusahaan. Hasil berbeda diperoleh Panjalusman et al. (2018) serta Falbo \& Firmansyah (2018), yaitu transfer pricing aggressivenes tidak berpengaruh terhadap penghindaran pajak.

Resesi ekonomi terjadi di Indonesia juga menjadi perhatian dalam penelitian ini. Merujuk pada publikasi terbaru Badan Pusat Statistik (BPS), angka pertumbuhan ekonomi nasional berada di minus $0,74 \%$ pada kuartal pertama tahun 2021 yang berarti bahwa pertumbuhan ekonomi domestik telah mencapai angka negatif selama empat kuartal berturut-turut. Sebelumnya di kuartal kedua 2020 mencapai $-5,32 \%$, kemudian di kuartal ketiga 2020 sebesar $-3,49 \%$ dan kuartal keempat 2020 berada di angka -2,19\% (Bastian, 2021). Kondisi ini bukan hanya 
disebabkan oleh pandemi Covid-19, tetapi juga dipengaruhi berbagai ketidakpastian global yang terjadi sebelumnya misalnya adanya perang dagang diantara China dan Amerika Serikat yang kian memanas.

Performa ekonomi yang memburuk dapat berpengaruh pada penurunan profit usaha yang menjadi sumber pembiayaan sehingga dapat menyebabkan terjadinya financial constraints yang menahan perusahaan dalam berinvestasi dan melakukan ekspansi bisnis (Bank Indonesia, 2009). Financial constraints merupakan sebuah kondisi perusahaan yang mengalami permasalahan mengenai keterbatasan atas kas perusahaannya. Financial constraints mengacu pada kondisi perusahaan dengan pendanaan internal yang terbatas (Koh \& Lee, 2015). Perusahaan yang mengalami financial constraints akan memaksimalkan sumber pendanaan internal dengan mengurangi biaya yang dikeluarkan (Edwards et al., 2016). Perusahaan yang mengalami financial constraints cenderung menyimpan kas dengan melakukan tax avoidance yang bertujuan untuk meningkatkan investasi di masa depan. (Chen \& Lai, 2012).

Penelitian sebelumnya yang membahas pengaruh financial constraints terhadap penghindaran pajak dilakukan oleh Edwards et al. (2013) dan menunjukan bahwa financial constraints berpengaruh positif terhadap tax avoidance dengan pengurangan pembayaran pajak secara kas yang ternyata dapat meningkatkan arus kas operasi dari perusahaan dalam kondisi financial constraints. Firmansyah \& Bayuaji (2019) mengungkapkan bahwa perusahaan yang mengalami kondisi financial constraints cenderung akan melakukan praktik agresivitas pajak karena perusahaan akan menggunakan manajemen pajak sebagai cara untuk meningkatkan pendanaan internal ketika perusahaan memiliki keterbatasan pendanaan. Hasil yang sama diperoleh dari penelitian yang dilakukan oleh Rachmawati \& Fitriana (2021) bahwa jika semakin besar nilai financial constraints maka perusahaan akan cenderung melakukan tindakan agresivitas pajak.

Berdasarkan uraian latar belakang yang telah dikemukakan penulis, serta masih adanya perbedaan hasil dan kesimpulan dari penelitian-penelittian sebelumnya, maka penulis tertarik untuk melakukan penelitian terkait praktik penghindaran pajak pada sektor manufaktur di Indonesia. Lebih jauh lagi, penelitian ini meneliti bagaimana pengaruh variabel-variabel dependen yang dijelaskan di atas, yaitu thin capitalization, transfer pricing aggressiveness terhadap penghindaran pajak dengan financial constraints sebagai variabel moderasi

\section{STUDI LITERATUR}

Wajib Pajak berusaha mencari cara agar dapat meminimalkan kewajiban pajaknya. Sistem perpajakan self assessment yang berlaku di Indonesia membuka peluang Wajib Pajak untuk mengurangi besarnya pajak terutang atau yang sering disebut dengan penghindaran pajak (tax avoidance). Hanlon \& Heitzman (2010) menjelaskan suatu penghindaran pajak merupakan aktivitas pengurangan nominal pajak secara eksplisit dari pendapatan sebelum pajak. Definisi penghindaran pajak secara luas diungkapkan Richardson (2006) sebagai perencanaan pajak dengan tujuan untuk menurunkan pendapatan kena pajak yang mencakup aktivitas legal dan ilegal. Penghindaran pajak dilakukan dalam rangka penghematan pajak yang lebih besar bagi perusahaan sehingga dapat mengurangi jumlah beban pajak untuk meningkatkan laba. Frank et al., (2009) menggunakan istilah yang lebih luas yaitu agresivitas pajak yang merupakan aktivitas pengurangan besarnya laba kena pajak melalui strategi perencanaan pajak yang dapat maupun tidak dapat dikategorikan sebagai tindakan penggelapan pajak. Aktivitas ini memanfaatkan grey area yaitu keadaan yang terindikasi dikenai pajak, tetapi belum terdapat aturan yang diterapkan untuk menentukan legalitasnya.

Thin capitalization merupakan situasi di mana perusahaan dibiayai melalui utang yang tinggi dibanding modal yang dimiliki atau highly leveraged. Semakin tinggi level utang dalam suatu perusahaan, maka semakin tinggi juga beban bunga yang harus dibayarkan sehingga laba fiskal semakin berkurang (OECD, 2012). Penghasilan kena pajak dapat menjadi semakin kecil karena dalam peraturan perpajakan, bunga utang merupakan pengurang penghasilan (deductible expense). Oleh karena itu, perusahaan dapat memanfaatkan insentif berupa pengurangan besarnya pajak akibat adanya beban bunga.

Transfer price adalah harga yang dibebankan oleh suatu divisi terhadap barang atau jasa yang diberikan kepada divisi lain dalam organisasi yang sama (Horngren et al., 2015). Hal ini senada 
dengan Hansen \& Mowen (2005) yang menyatakan bahwa transfer price dalam suatu perusahaan atau grup perusahaan adalah harga yang dibebankan oleh divisi penjulan kepada divisi pembelian. Menurut arti yang lebih luas, transfer price adalah harga transfer barang, jasa, maupun aset tak berwujud dalam transaksi antara suatu perusahaan dengan pihak berelasi (OECD, 2009). Gusnardi (2009) menjelaskan bahwa transfer pricing digunakan perusahaan multinasional untuk meminimalkan kewajiban pajak mereka secara global. Sebagaimana menurut Richardson et al. (2013), transfer pricing aggressiveness dicerminkan dari transaksi tidak wajar yang timbul diantara pihak-pihak yang berelasi. Eden \& Smith (2011) menyatakan bahwa transfer pricing aggressiveness adalah suatu upaya memperkecil jumlah pajak yang terutang dengan memperkecil penghasilan atau memperbesar biaya. Berdasarkan berbagai penjelasan di atas dapat ditarik kesimpulan bahwa dalam penelitian ini transfer pricing aggressiveness merupakan penetapan harga di antara pihak-pihak yang memiliki hubungan istimewa yang dapat memengaruhi after tax income perusahaan.

Financial constraints adalah kondisi perusahaan yang mengalami permasalahan mengenai keterbatasan atas kas perusahaannya sehingga kesulitan dalam mengambil kesempatan investasi. Edwards et al. (2016) mengungkapkan bahwa perusahaan yang mengalami financial constraints akan berusaha semaksimal mungkin menggunakan sumber pendanaan yang berasal dari internal dengan cara berusaha mengurangi biaya-biaya yang terjadi, salah satunya adalah biaya pajak karena dianggap tidak memengaruhi kinerja perusahaan dalam jangka panjang. Senada dengan hal tersebut, Chen \& Lai (2012) menyatakan bahwa ketika suatu perusahaan sedang mengalami financial constraints maka ketersediaan operating cash flow menjadi hal yang krusial sehingga perusahaan memiliki insentif yang lebih untuk menghasilkan operating cash flow yang lebih tinggi dengan cara melakukan penghindaran pajak.

Penelitian mengenai praktik penghindaran pajak telah banyak dilakukan sebelumnya. Beberapa penelitian terdahulu menguji hubungan antara thin capitalization, transfer pricing aggressiveness, dan financial constraints terhadap penghindaran pajak. Taylor \& Richardson (2012) melakukan penelitian praktik penghindaran pajak internasional pada 203 perusahaan yang terdaftar pada bursa efek Australia tahun 2006 sampai dengan 2009. Penelitian ini menguji pengaruh transfer pricing, thin capitalization, multinationality, income shifting, serta tax haven utilization terhadap penghindaran pajak. Pengukuran transfer pricing yang digunakan yaitu dengan pendekatan sumscore dilakukan untuk menentukan indeks dengan 8 (delapan) indikator, thin capitalization diukur dengan MAD ratio, serta penghindaran pajak diukur dengan Long Run ETR dan Book Tax Difference (BTD). Hasil penelitian menunjukkan bahwa transfer pricing, thin capitalization, multinationality, income shifting, serta tax haven utilization berhubungan secara signifikan dengan penghindaran pajak. Transfer pricing serta thin capitalization menjadi pendorong utama penghindaran pajak. Penelitian tersebut juga menunjukkan bahwa terdapat kecenderungan penggunaan tax haven utilization secara bersaman dengan transfer pricing dan thin capitalization dalam upaya memanfaatkan peluang penghindaran pajak internasional.

Amidu et al. (2019) mendapatkan hasil serupa terkait pengaruh positif transfer pricing aggressiveness terhadap praktik penghindaran pajak dengan melakukan penelitian di 40 perusahaan Multi Nasional Company (MNC) Ghana baik bidang financial dan nonfinancial dalam kurun waktu 2008 s.d. 2015. Penelitian ini menggunakan proksi ETR untuk mengukur penghindaran pajak, yaitu beban pajak perusahaan yang telah dikurangi beban pajak tangguhan dibandingkan dengan laba bersih sebelum pajak sedangkan transfer pricing diukur dengan indeks sumscore melalui 5 (lima) indikator.

Penelitian mengenai pengaruh thin capitalization dan transfer pricing aggressiveness terhadap penghindaran pajak juga telah dilakukan di Indonesia. Falbo \& Firmansyah (2018) menguji pengaruh thin capitalization dan transfer pricing aggressiveness terhadap penghindaran pajak dengan menggunakan sampel 90 perusahaan manufaktur selama periode tahun 2013 s.d. 2015. Thin capitalization dalam penelitian ini menggunakan MAD ratio sebagaimana digunakan dalam penelitian Taylor dan Richardson (2012) dengan menyesuaikan batas rasio utang terhadap ekuitas sesuai PMK nomor 169/PMK.010/2015 yang berlaku di Indonesia. Pengukuran transfer pricing aggressiveness menggunakan indeks sumscore dengan 7 (tujuh) indikator dan proksi penghindaran pajak yang digunakan yaitu abnormal book-tax difference (ABTD). Hasil yang 
diperoleh yaitu thin capitalization memiliki pengaruh positif terhadap penghindaran pajak, tetapi transfer pricing aggressiveness tidak memiliki pengaruh terhadap penghindaran pajak. Hasil yang serupa diperoleh Panjalusman et al. (2018) dalam menguji pengaruh transfer pricing terhadap penghindaran pajak dengan menggunakan sampel 9 perusahaan manufaktur selama periode tahun 2014 s.d. 2017. Transfer pricing diukur melalui perbandingan piutang usaha kepada pihak yang memiliki hubungan istimewa terhadap total piutang yang dimiliki dan penghindaran pajak diukur dengan Cash ETR. Penelitian ini menyimpulkan bahwa hasil yang diperoleh dimungkinkan akibat dari beberapa faktor, yaitu pergantian sistem pemerintahan serta timbulnya banyak kebijakan-kebijakan baru misalnya Tax Amnesty dan lain sebagainya.

Nadhifah \& Arif (2020) juga menguji pengaruh thin capitalization dan transfer pricing aggressiveness terhadap penghindaran pajak sebagaimana telah dilakukan oleh Falbo \& Firmansyah (2018) sebelumnya. Penelitian terhadap 32 perusahaan manufaktur yang terdaftar di BEI pada periode tahun 2016 s.d. 2018 ini menyimpulkan bahwa thin capitalization berpengaruh positif terhadap penghindaran pajak, tetapi transfer pricing memiliki pengaruh negatif terhadap penghindaran pajak. Transfer pricing diukur dengan indeks sumscore melalui 5 (lima) indikator sebagaimana dalam penelitian Amidu et al. (2019), thin capitalization dirumuskan dengan MAD ratio, serta penghindaran pajak diukur menggunakan proksi Effective Tax Rate (ETR) yang telah dimodifikasi oleh Yorke et al. (2016). Hasil yang berbeda terkait pengaruh thin capitalization diperoleh Nainggolan dan Sari (2019) yang menguji pengaruh karakteristik perusahaan multinasional terhadap agresivitas pajak di Indonesia. Penelitian ini dilakukan terhadap 150 perusahaan yang terdaftar di BEI pada tahun 2011 sampai dengan 2015. Penelitian ini menunjukkan bahwa thin capitalization tidak terbukti memiliki pengaruh terhadap praktik agresivitas pajak.

Penelitian Chen \& Lai (2012) menguji pengaruh financial constraints terhadap penghindaran pajak. Beberapa proksi untuk mengukur financial constraints digunakan dalam penelitian ini antara lain indeks Whited dan Wu (WW), indeks Kaplan dan Zingales (KZ), serta menggunakan dividend payout ratio (Fazzari et al., 1988). Penelitian tersebut menyimpulkan bahwa dalam kondisi financial constraints, perusahaan menjadi lebih agresif melakukan tindakan penghindaran pajak dengan ditunjukkan adanya pelaporan tarif pajak yang lebih rendah 3-8 \%.

Penelitian yang menguji pengaruh financial constraints terhadap penghindaran pajak juga telah dilakukan di Indonesia. Firmansyah \& Bayuaji (2019) melakukan penelitian terhadap perusahaan manufaktur yang terdaftar di BEI pada tahun 2011-2015 dengan menggunakan indeks Whited dan $\mathrm{Wu}$ (2006) untuk mengukur financial constraints sebagaimana dilakukan oleh Edwards et al. (2016) dan Chen \& Lai (2012). Agresivitas pajak diukur dengan menggunakan book tax difference sebagaimana dikembangkan oleh Lim (2011). Penelitian ini menyimpulkan bahwa financial constraints berpengaruh positif terhadap agresivitas pajak perusahaan. Hasil yangs serupa diperoleh melalui penelitian Rachmawati dan Fitriana (2021) pada perusahaan manufaktur yang terdaftar di BEI pada tahun 2016-2018. Proksi yang digunakan untuk mengukur financial constraints merupakan analisis faktor konfirmatori yang terdiri dari tiga ukuran antara lain rasio utang bersih, rasio cakupan bunga, serta rasio pembayaran dividen. Analisis faktor konfirmatori ini dinilai mampu dengan tepat mengevaluasi validitas konstruk sehingga mampu menyederhanakan interpretasi hasil serta ukuran yang digunakan lebih komprehensif. Proksi yang digunakan dalam mengukur agresivitas pajak yaitu net profit margin (NPM).

Hipotesis dalam penelitian ini adalah sebagai berikut:

H1: Thin capitalization berpengaruh positif terhadap penghindaran pajak

H2: Transfer pricing aggressiveness berpengaruh positif terhadap penghindaran pajak

H3: Financial constraints berpengaruh positif terhadap penghindaran pajak

H4: Financial constraints memperkuat pengaruh positif thin capitalization terhadap penghindaran pajak

H5: Financial constraints memperkuat pengaruh positif transfer pricing aggressiveness terhadap penghindaran pajak 


\section{METODE}

Penelitian ini dilakukan menggunakan pendekatan metode kuantitatif dengan memanfaatkan data sekunder berupa laporan keuangan dan laporan tahunan dari Bursa Efek Indonesia (BEI). Populasi dari penelitian ini adalah perusahaan di bidang manufaktur yang terdaftar di BEI dalam periode waktu 2016 sampai dengan 2019. Dari populasi tersebut, dilakukan pemilihan sampel yang selanjutnya akan diolah dan dianalisis sesuai metode yang telah ditentukan. Sampel dipilih dengan metode purposive sampling yaitu teknik penentuan sampel dengan beberapa kriteria tertentu yang ditetapkan oleh peneliti. Tabel 2 menunjukkan kriteria eliminasi sampel dan hasil pemilihan sampel penelitian.

Tabel 2. Kriteria dan Hasil Pemilihan Sampel Penelitian

\begin{tabular}{|l|c|}
\hline \multicolumn{1}{|c|}{ Kriteria } & Jumlah \\
\hline Perusahaan manufaktur yang terdaftar di BEI pada tahun 2019 & 182 \\
\hline Eliminasi & $(41)$ \\
$-\quad$ Perusahaan manufaktur yang terdaftar setelah 01 Januari 2016 & $(28)$ \\
$-\quad$ Perusahaan manufaktur yang pelaporan keeuangannya menggunakan & $(4)$ \\
mata uang asing & Perusahaan manufaktur yang diketahui tidak memiliki data lengkap \\
- Perusahaan yang laba sebelum pajak negatif/rugi selama masa observasi & $(37)$ \\
\hline tahun 2016 - 2019 & 72 \\
Jumlah perusahaan & 4 \\
Jumlah tahun (2016 s.d. 2019) & 288 \\
\hline
\end{tabular}

Sumber: Diolah penulis (2021)

Variabel dependen yang digunakan dalam penelitian ini yaitu penghindaran pajak. Penulis menggunakan GAAPETR sebagai proksi penghindaran pajak dalam penelitian ini. Penggunaan proksi ini sejalan dengan penelitian yang dilakukan oleh (Dyreng et al., 2010).

GAAPETR $=\frac{\text { Beban Pajak }}{\text { Laba Sebelum Pajak }}$

Terdapat dua variabel independen yang digunakan dalam penelitian ini yaitu thin capitalization dan transfer pricing aggressiveness serta financial constraints sebagai variabel moderasi yang juga diletakkan pada posisi variabel independen.

Pengukuran thin capitalization dengan cara menghitung MAD ratio sebagaimana digunakan oleh Taylor \& Richardson (2012), yaitu dilakukan melalui menghitung besarnya safe harbor debt amount (SHDA) dengan cara rata-rata total aset dikurangi non-interest bearing liability (nonIBL) dan dikalikan dengan $80 \%$ serta menghitung besarnya maximum allowable debt (MAD) ratio yang merupakan rata-rata total utang dibagi dengan SHDA.

\begin{tabular}{rl|}
\hline SHDA & $=($ Average Total Assets - nonIBL $) \times 80 \%$ \\
$M A D$ ratio & $=\frac{\text { Average debt }}{\text { SHDA }}$
\end{tabular}

Pengukuran transfer pricing aggressiveness yang digunakan dalam penelitian ini sebagaiamana penelitian Richardson et al. (2013) yaitu melalui pendekatan sumscore untuk menentukan indeks dengan cara menghitung jumlah indikator yang diambil dari laporan keuangan dan laporan tahunan perusahaan. Setiap indikator diberikan nilai 1 jika ada dan 0 jika sebaliknya kemudian hasilnya dibagi dengan tujuh. Pendekatan sumscore dengan beberapa indikator ini digunakan dalam penelitian karena mempertimbangkan arm's length principle serta dinilai lebih dapat merepresentasikan kondisi sebenarnya daripada hanya penilaian atas ada 
Owner: Riset \& Jurnal Akuntansi

e-ISSN : 2548-9224 | p-ISSN : 2548-7507

Volume 6 Nomor 1, Januari 2022

DOI : https://doi.org/10.33395/owner.v6i1.607

tidaknya transaksi dengan pihak berelasi. Adapun indikator-indikator yang digunakan dalam penelitian ini yaitu:

1. Adanya utang/piutang pihak berelasi tanpa bunga

2. Adanya utang/piutang pihak berelasi yang dibebaskan

3. Adanya utang/piutang pihak berelasi dengan impairment

4. Adanya kewajiban nonmoneter antarpihak berelasi

5. Tidak adanya dokumen formal terkait metode transfer pricing yang digunakan

6. Adanya pelepasan aset jangka panjang dari pihak berelasi dengan tidak disertai justifikasi komersial

7. Tidak ada justifikasi transaksi secara wajar antarpihak berelasi

Penelitian ini menggunakan financial constraints di posisi variabel independen dan juga sekaligus variabel moderasi. Financial constraints dalam penelitian ini menggunakan pendekatan indeks Whited \& Wu (2006) yang digunakan oleh Chen \& Lai (2012) dan Edwards et al. (2013). Indeks Whited dan Wu (Indeks WW) digunakan sebab dinilai mampu memprediksi kendala keuangan eksternal yang dapat memengaruhi investasi. Indeks WW dapat dihitung dengan cara sebagai berikut.

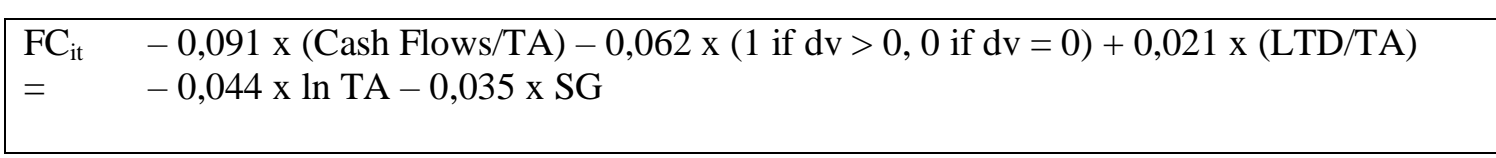

Keterangan:

\begin{tabular}{|c|c|}
\hline $\mathrm{FC}$ & $=$ Financial Constraints \\
\hline TA & $=$ Total Assets \\
\hline Dv & $=$ Dividend paid \\
\hline $\begin{array}{l}\text { LTD } \\
\text { SG }\end{array}$ & $\begin{array}{l}=\text { Total Long Term Debt } \\
=\left(\text { Sales }_{-}-\text {Sales }_{1}\right) / \text { Sale }\end{array}$ \\
\hline
\end{tabular}

Untuk meminimalkan adanya kesalahan yang mungkin timbul dalam proses pengujian, penelitian ini menggunakan variabel kontrol return on asset (ROA), inventory intensity (INVINT), dan leverage (LEV). ROA dihitung dari laba sebelum pajak dibagi total aset sebagaimana penelitian Taylor \& Richardson (2012). INVINT diukur dengan persediaan dibagi dengan total aset sebagaimana penelitian Richardson \& Lanis (2007). LEV diukur dengan cara membagi utang jangka panjang dengan total aset sebagaimana penelitian Taylor \& Richardson (2012).

Analisis regresi linear berganda digunakan untuk menguji pengaruh thin capitalization, transfer pricing aggressiveness, dan financial constraints terhadap penghindaran pajak sebagaimana hipotesis 1 s.d. 3 dengan model 1 sebagai berikut:

GAAPETR $=\beta 0+\beta 1$ THIN $+\beta 2$ TPRICE $+\beta 3$ FC $+\beta 4$ ROA $+\beta 5$ INVINT + $\beta 6 \mathrm{LEV}+\varepsilon$

Selanjutnya analisis regresi metode interaksi digunakan untuk menganalisis peran financial constraints dalam memoderasi pengaruh thin capitalization, transfer pricing aggressiveness terhadap penghindaran pajak sebagaimana hipotesis 4 s.d. 5 dengan model 2 sebagai berikut:

GAAPETR $=\beta 0+\beta 1 \mathrm{THIN}+\beta 2 \mathrm{TPRICE}+\beta 3 \mathrm{FC}+\beta 4 \mathrm{THIN} * \mathrm{FC}+$ $\beta 6$ TPRICE*FC $+\beta$ 7ROA $+\beta 8$ INVINT $+\beta 9$ LEV $+\varepsilon$

$\begin{array}{ll}\text { Keterangan: } & \\ \text { GAAPETR } & =\text { penghindaran pajak } \\ \text { THIN } & =\text { thin capitalization } \\ \text { TPRICE } & =\text { transfer pricing aggressiveness } \\ \text { FC } & =\text { financial constraints } \\ \text { ROA } & =\text { return } \text { on asset }\end{array}$




$\begin{array}{ll}\text { INVINT } & =\text { inventory intensity } \\ \text { LEV } & =\text { leverage } \\ \beta & =\text { konstanta } \\ \varepsilon & =\text { error }\end{array}$

\section{HASIL}

Uji normalitas dalam penelitian ini dilakukan melalui pengamatan pada probabilitas JarqueBera. Apabila nilai probabilitas Jarque-Bera lebih besar dari $\alpha(0,05)$ maka data telah berdistribusi dengan normal sedangkan jika nilainya lebih kecil dari $\alpha(0,05)$ maka data tidak berdistribusi normal. Dari hasil uji diketahui bahwa nilai Jarque-Bera pada model 1 dan model 2 adalah samasama sebesar 0,0000. Dengan nilai Jarque-Bera lebih kecil dari $\alpha(0,05)$ berarti bahwa data residual pada penelitian ini tidak berdistribusi normal. Berdasarkan Central Limit Theorema (CLT), penelitian yang dilakukan pada jumlah pengamatan yang besar tidak perlu mempermasalahkan normalitas karena normalitas memiliki peranan penting hanya ketika jumlah data pengamatannya kecil. Batas jumlah pengamatan dapat dikategorikan dalam jumlah besar jika memiliki jumlah pengamatan lebih besar dari 100 (Gujarati \& Porter, 2012). Jumlah data observasi pada penelitian ini adalah sebesar 288 data sehingga berdasarkan CLT distribusi residual data observasi memenuhi asumsi normal.

Hasil uji multikolinearitas pada model 1 menunjukkan seluruh nilai koefisien korelasi antarvariabel independen pada penelitian ini tidak ada yang memiliki nilai koefisien lebih dari 0,9 sehingga disimpulkan bahwa tidak terjadi multikolinearitas antarvariabel independen pada model 1 penelitian. Sedangkan pada model 2 terdapat masalah multikolinearitas antara variabel THIN dengan THIN*FC. Menurut Sugiono (2004). meskipun dalam sebuah model penelitian terdapat masalah estimasi statistik karena adanya multikolinearitas, hal tersebut tidak bersifat problematis untuk pembentukan pengaruh keberadaan moderasi.

Uji autokorelasi pada penelitian ini menggunakan Uji Breusch-Godfrey Serial Correlation LM. Pada hasil uji Breusch-Godfrey Serial Correlation LM didapatkan probabilitas model 1 dan model 2 sebesar 0,6019 dan 0,6047. Nilai probabilitas tersebut lebih tinggi dari tingkat signifikansi $\alpha(0,05)$ yang berarti tidak ada autokorelasi dalam kedua model ini.

Uji heteroskedastisitas dilakukan melalui uji glejser, yaitu dengan meregresikan variabelvariabel independen terhadap nilai absolut residualnya (Gujarati \& Porter, 2012). Berdasarkan hasil uji glejser, nilai Prob. dari variabel THIN, TPRICE pada model 1 serta variabel ROA pada model 1 dana 2 berada di bawah nilai $\alpha(0,05)$ yang berarti terdapat masalah heteroskedastisitas. Masalah heteroskedastisitas dapat ditangani dengan menggunakan estimator Feasible Generalized Least Square (FGLS) dengan memilih opsi cross-section weights. Oleh karena itu, untuk mengatasi masalah heteroskedastisitas dalam penelitian ini digunakan estimator crosssection weights.

Berdasarkan hasil uji asumsi klasik, hasil regresi, nilai koefisien determinasi, hasil uji-F, serta uji-t penelitian ini disajikan dalam Tabel 3.

Tabel 3. Hasil Uji Regresi Model Penelitian

\begin{tabular}{|l|c|c|c|c|c|c|}
\hline \multirow{2}{*}{ Variabel } & \multicolumn{3}{|c|}{ Model 1 } & \multicolumn{3}{c|}{ Model 2 } \\
\cline { 2 - 7 } & Koef. & $\begin{array}{c}\text { two- } \\
\text { tailed }\end{array}$ & $\begin{array}{c}\text { one- } \\
\text { tailed }\end{array}$ & Koef. & $\begin{array}{c}\text { two- } \\
\text { tailed }\end{array}$ & $\begin{array}{c}\text { one- } \\
\text { tailed }\end{array}$ \\
\hline THIN & -0.07937 & 0.0000 & 0.0000 & -0.26162 & 0.0015 & 0.0008 \\
\hline TPRICE & -0.12570 & 0.0000 & 0.0000 & 0.04479 & 0.8872 & 0.4436 \\
\hline FC & -0.07872 & 0.0431 & 0.0216 & 0.01013 & 0.9523 & 0.4762 \\
\hline ROA & 0.11751 & 0.0092 & 0.0046 & 0.09872 & 0.0292 & 0.0146 \\
\hline INVINT & 0.12384 & 0.0004 & 0.0002 & 0.13820 & 0.0003 & 0.0002 \\
\hline LEV & 0.04679 & 0.2063 & 0.1032 & -0.00473 & 0.9110 & 0.4555 \\
\hline THIN*FC & & & & -0.30178 & 0.0206 & 0.0103 \\
\hline
\end{tabular}


Owner: Riset \& Jurnal Akuntansi

e-ISSN : 2548-9224 | p-ISSN : 2548-7507

Volume 6 Nomor 1, Januari 2022

DOI : https://doi.org/10.33395/owner.v6i1.607

\begin{tabular}{|l|c|c|c|c|c|c|}
\cline { 5 - 7 } TPRICE*FC & & & 0.18374 & 0.6834 & 0.3417 \\
\hline C & 0.22409 & 0.0000 & & 0.26213 & 0.0174 & 0.0087 \\
\hline R-Squared & 0.12865 & & & 0.15651 & & \\
\hline Adj. R-Squared & 0.11005 & & & 0.13232 & & \\
\hline F-Statistic & 6.91489 & & & 6.47098 & & \\
\hline Prob. (F Statistic) & 0.00000 & & & 0.00000 & & \\
\hline
\end{tabular}

Sumber: Diolah penulis dari aplikasi Eviews 9 (2021)

Berdasarkan hasil analisis regresi pada Tabel 3, maka diperoleh persamaan regresi sebagai berikut:

GAAPETR $=0,22409-0,07937$ THIN $-0,12570$ TPRICE $-0,07872$ FC +

$0,11751 \mathrm{ROA}+0,12384 \mathrm{INVINT}+0,04679 \mathrm{LEV}+\varepsilon$

GAAPETR $=0,26213-0,26162$ THIN $+0,04479$ TPRICE $+0,01013$ FC -

0,30178 THIN $*$ FC $+0,18374$ TPRICE*FC $+0,09872$ ROA $+\ldots$.

0,13820 INVINT $-0.00473 \mathrm{LEV}+\varepsilon$

Analisis koefisien determinasi (R2) diperlukan pada pengukuran kemampuan model dalam menerangkan variasi dalam variabel dependen (Ghozali, 2016). Berdasarkan Tabel 3, nilai R2 dalam model 1 dan model 2 penelitian ini adalah 0,12865 dan 0,15651. Hal ini berarti bahwa variasi nilai penghindaran pajak yang mampu dijelaskan oleh variabel independen dalam model 1 penelitian ini sebesar $12,87 \%$ dan dalam model 2 penelitian ini sebesar 15,65\%. Dengan demikian, variasi nilai penghindaran pajak sebesar $87,13 \%$ pada model 1 dan $84,35 \%$ pada model 2 dijelaskan oleh faktor lain di luar model penelitian.

Berdasarkan hasil uji statistik t pada model 1 yang ditunjukkan dalam Tabel 3 dapat diketahui bahwa variabel THIN mempunyai koefisien -0,07937 dan probabilitas (one-tailed) sebesar 0,0000 . Nilai probabilitas (one-tailed) sebesar 0,0000 yang lebih kecil dari $\alpha(0,05)$ menunjukkan bahwa variabel THIN secara individu berpengaruh signifikan terhadap GAAPETR dengan arah negatif. Dalam penelitian ini GAAPETR memiliki hubungan terbalik dengan penghindaran pajak, semakin besar GAAPETR maka penghindaran pajak semakin kecil dan sebaliknya. Hubungan tersebut berarti THIN berpengaruh signifikan positif terhadap penghindaran pajak. Kesimpulan dari hasil ini menunjukkan bahwa hipotesis pertama diterima yaitu thin capitalization berpengaruh positif terhadap penghindaran pajak.

Variabel TPRICE memiliki nilai koefisien -0,12570 dan probabilitas (one-tailed) 0,0000 berada di bawah nilai $\alpha(0,05)$ yang berarti variabel TPRICE memiliki pengaruh negatif signifikan terhadap GAAPETR. Dengan demikian, TPRICE berpengaruh positif signifikan terhadap penghindaran pajak sehingga hipotesis kedua diterima.

Variabel FC memiliki nilai koefisien -0,07872 dan probabilitas (one-tailed) 0,0216 lebih kecil dari tingkat signifikansi $\alpha(0,05)$ yang berarti bahwa variabel FC berpengaruh negatif signifikan terhadap GAAPETR. Dengan demikian, FC berpengaruh positif signifikan terhadap penghindaran pajak sehingga hipotesis ketiga diterima.

Berdasarkan hasil uji signifikansi simultan (Uji F) yang ditampilkan pada Tabel 3, nilai probabilitas F-statistic pada model 1 dan model 2 sebesar 0,00000. Nilai tersebut lebih rendah dari tingkat signifikansi $\alpha(0,05)$, hal ini menjelaskan bahwa seluruh variabel independen yang terdapat pada model 1 dan model 2 secara bersama-sama memberikan pengaruh terhadap variabel dependen yaitu penghindaran pajak.

Berdasarkan hasil uji statistik t pada model 1 yang ditunjukkan dalam Tabel 3, variabel THIN*FC memiliki nilai probabilitas (one-tailed) 0,0103 lebih kecil dari $\alpha(0,05)$ sehingga dapat disimpulkan bahwa financial constraints memoderasi pengaruh thin capitalization terhadap penghindaran pajak. Selanjutnya untuk melihat variabel moderasi financial constraints (FC) tersebut memperkuat atau memperlemah hubungan variabel independen terhadap variabel 
dependen maka dilakukan uji interaksi dengan melihat koefisien regresi pada variabel THIN dan THIN*FC. Nilai koefisien variabel THIN adalah sebesar $-0,07937$ dan variabel THIN*FC adalah sebesar -0,30178. Nilai koefisien THIN dan THIN*FC tersebut sama-sama negatif (searah) maka moderasi memperkuat pengaruh variabel independen terhadap variabel dependen. Dengan demikian hasil ini menunjukkan bahwa hipotesis keempat diterima yaitu financial constraints memperkuat pengaruh positif thin capitalization terhadap penghindaran pajak.

Variabel TPRICE*FC memiliki nilai probabilitas (one-tailed) sebesar 0,3417. Nilai probabilitas tersebut lebih besar dari tingkat signifikansi $\alpha(0,05)$ sehingga dapat disimpulkan bahwa financial constraints tidak memoderasi pengaruh transfer pricing aggressiveness terhadap penghindaran pajak. Berdasarkan hasil pengujian, dapat disimpulkan bahwa financial constraints tidak memperkuat pengaruh positif transfer pricing aggressiveness terhadap penghindaran pajak yang berarti bahwa hipotesis kelima ditolak.

\section{PEMBAHASAN}

Hasil yang ditunjukkan dalam penelitian ini yaitu thin capitalization berpengaruh positif terhadap penghindaran pajak. Semakin tinggi thin capitalization yang dilakukan perusahaan, maka semakin tinggi pula kecenderungan perusahaan dalam menggunakan utang pada pembiayaannya sehingga semakin besar pula kemungkinan penghindaran pajak yang dilakukan. Thin capitalization merupakan salah satu pendorong utama penghindaran pajak karena mampu memberikan insentif kepada perusahaan untuk mengurangi penghasilan kena pajak melalui pembebanan bunga pinjaman (Taylor \& Richardson, 2012). Penghasilan kena pajak dapat menjadi lebih kecil karena menurut peraturan perpajakan, beban bunga atas utang merupakan pengurang penghasilan (deductible expense). Celah ini dapat dimanfaatkan perusahaan untuk menurunkan beban pajak sehingga mengoptimalkan pendapatan perusahaan melalui penghindaran pajak. Hasil penelitian ini sesuai dengan penelitian Taylor \& Richardson (2012); Falbo \& Firmansyah (2018); Nadhifah \& Arif (2020); Jumailah (2020) yang menyimpulkan bahwa thin capitalization berpengaruh positif terhadap penghindaran pajak. Senada dengan hal tersebut, penelitian Taylor \& Richardson (2012) yang dilakukan terhadap perusahaan terdaftar di bursa Australia menyebutkan thin capitalization merupakan salah satu pendorong utama penghindaran pajak serta digunakan oleh perusahaan terbuka di Australia sebagai alat penghindaran pajak internasional.

Berdasarkan pengujian yang telah dilakukan diperoleh hasil bahwa transfer pricing aggressiveness berpengaruh positif terhadap penghindaran pajak. Hasil ini sejalan dengan penelitian Taylor \& Richardson (2012) dan Amidu et al. (2019) yang menunjukkan bahwa semakin tinggi agresivitas transfer pricing suatu perusahaan maka semakin tinggi pula tingkat penghindaran pajak yang dilakukan. Transfer pricing aggressiveness merupakan manfaat pajak ataupun keuangan yang didapat suatu perusahaan ketika menggunakan perbedaan keuangan, ekonomi serta peraturan antar wilayah yurisdiksi yang tidak sama (Eden \& Smith, 2011). Potensi penghindaran pajak cukup besar muncul pada transaksi antarpihak berelasi yang berlokasi di berbagai wilayah yurisdiksi perpajakan (Desai \& Dharmapala, 2006). Perusahaan multinasional akan dapat meminimalisasi pajaknya dengan cara mengatur harga transfer antar perusahaan yang berelasi (Grubert \& Mutti, 1991). Oleh karena itu, perusahaan multinasional memiliki kesempatan untuk mengatur harga transfer dalam transaksi antar perusahaan berelasi di negara yang berbeda dalam rangka melakukan praktik penghindaran pajak. Jika dihubungkan dengan teori keagenan, manajer selaku agen akan mengambil keputusan sesuai dengan kepentingannya untuk mengatur harga transfer kepada pihak yang memiliki hubungan istimewa dalam rangka mengoptimalkan pendapatan global mereka. Oleh karena itu, peningkatan transfer pricing akan berdampak pada peningkatan penghindaran pajak yang dilakukan oleh perusahaan.

Hasil pengujian yang dilakukan menunjukan bahwa financial constraints berpengaruh positif terhadap penghindaran pajak. Semakin tinggi kondisi financial constraints akan meningkatkan kemungkinan penghindaran pajak yang dilakukan perusahaan. Hasil yang serupa juga diperoleh melalui penelitian Chen \& Lai (2012); Edwards et al. (2016); Firmansyah \& Bayuaji (2019); Rachmawati \& Fitriana (2021) yang menyimpulkan bahwa perusahaan dengan kondisi financial constraints cenderung melakukan tindakan penghindaran pajak. Perusahaan dikatakan dalam 
kondisi financial constraints ketika suatu perusahaan tidak mempunyai cukup kas saat ada kesempatan berinvestasi dan ketika adanya biaya agensi saat masuk ke pasar keuangan (Prasetyowati, 2015). Ketersediaan operating cash flow menjadi hal yang krusial sehingga perusahaan memiliki insentif yang lebih tinggi untuk menghasilkan operating cash flow dengan memaksimalkan penggunaan sumber pendanaan internal melalui pengurangan biaya-biaya yang terjadi salah satunya adalah biaya pajak karena biaya tersebut dianggap tidak memengaruhi kinerja perusahaan dalam jangka panjang Edwards et al. (2016). Perusahaan dengan financial constraints melaporkan pajak 3\%-8\% lebih rendah dibandingkan perusahaan tanpa kondisi financial constraints Chen dan Lai (2012). Hasil penelitian ini memperkuat indikasi bahwa sumber pendanaan internal perusahaan dengan kondisi financial constraints dapat dipenuhi melalui praktik penghindaran pajak.

Berdasarkan pengujian yang telah dilakukan, financial constraints dapat memoderasi pengaruh thin capitalization terhadap penghindaran pajak. Hasil penelitian ini membuktikan adanya indikasi bahwa sumber pendanaan internal perusahaan dalam kondisi financial constraints dilakukan melalui praktik penghindaran pajak dengan skema thin capitalization. Perusahaan yang mengalami financial constraints merupakan perusahaan yang memiliki keterbatasan memperoleh pendanaan eksternal akibat tingginya cost of debt dan cost of equity (Fazzari et al., 1988). Keterbatasan dana dan sumber daya dapat membuat perusahaan kehilangan kesempatan untuk melakukan investasi. Oleh karena itu, ketika perusahaan sedang mengalami financial constraints maka ketersediaan operating cash flow menjadi hal yang krusial sehingga perusahaan berusaha meningkatkan sumber pendanaan internal untuk memenuhi kebutuhan investasi tersebut (Chen \& Lai, 2012). Melalui praktik penghindaran pajak yang agresif, perusahaan yang mengalami financial constraints dapat melakukan penghematan kas dalam rangka meningkatkan sumber pendanaan internal untuk menghadapi masalah kekurangan investasi (Firmansyah \& Bayuaji, 2019). Oleh karena itu, dapat dikatakan bahwa dalam kondisi financial constraints perusahaan cenderung melakukan penghindaran pajak dengan thin capitalization untuk meningkatkan sumber pendanaan internal perusahaan.

Hasil penelitian ini menunjukkan bahwa financial constraints tidak memoderasi pengaruh transfer pricing aggressiveness terhadap penghindaran pajak. Dapat dikatakan bahwa kondisi financial constraints yang dialami oleh suatu perusahaan tidak memperkuat pengaruh positif transfer pricing aggressiveness terhadap penghindaran pajak. Faktor yang diduga memengaruhi hasil penelitian ini yaitu adanya perhatian dari otoritas perpajakan dengan penerbitan Peraturan Menteri Keuangan Nomor 213/PMK.03/2016 tentang Jenis Dokumen dan/atau Informasi Tambahan yang Wajib Disimpan oleh Wajib Pajak yang Melakukan Transaksi dengan Para Pihak yang Mempunyai Hubungan Istimewa, dan Tata Cara Pengelolaannya. Kewajiban penyusunan transfer pricing document dapat menimbulkan biaya tambahan seperti biaya transportasi, akomodasi, perlengkapan, biaya untuk mendapatkan data pembanding serta hambatan lain baik dari sisi Wajib Pajak maupun otoritas perpajakan (Indah \& Fitria, 2019). Hal tersebut menyebabkan perusahaan dalam kondisi financial constraints akan lebih berhati-hati dalam menggunakan kas mereka sehubungan dengan biaya tambahan yang dikeluarkan serta hambatan lain yang dialami. Peraturan mengenai transfer pricing document di atas juga menjadikan penyusunan laporan keuangan lebih transparan dan lebih menghindari terjadinya kesalahan karena dijadikan salah satu dasar penyusunan dokumen tersebut. Transfer pricing document digunakan untuk membuktikan bahwa perhitungan pajak telah sesuai dengan arm's length principle (Kurniawan, 2015). Dokumen ini digunakan Wajib Pajak dalam penentuan harga transfer berdasarkan ketentuan perpajakan yang berlaku, kelengkapan dalam mengisi surat pemberitahuan (SPT), sebagai alat bukti pemeriksaan serta dalam upaya hukum yang diajukan misalnya keberatan, banding serta peninjauan kembali. Perusahaan dalam kondisi financial constraints diduga cenderung lebih berhati-hati dalam mengambil keputusan penghematan kas melalui praktik penghindaran pajak transfer pricing untuk meningkatkan sumber pendanaan internal mengingat kemungkinan adanya risiko lebih besar yang akan timbul bagi perusahaan. Hal ini disebabkan karena adanya risiko dikenakan denda atau sanksi apabila tidak dilakukan sesuai ketentuan sehingga dapat memperburuk kondisi keuangan perusahaan. 


\section{KESIMPULAN}

Berdasarkan hasil pengolahan dan analisis data yang telah dilakukan, dapat disimpulkan bahwa thin capitalization, transfer pricing aggressiveness dan financial constraints merupakan faktor pendorong perusahaan dalam melakukan penghindaran pajak. Melalui praktik thin capitalization, perusahaan dapat memanfaatkan fasilitas pengurangan beban bunga pinjaman sehingga pajak yang dikenakan menjadi lebih kecil. Perusahaan cenderung melakukan transfer pricing aggressiveness dengan pihak yang memiliki hubungan istimewa untuk mengoptimalkan pendapatan global mereka melalui penghindaran pajak. Kondisi financial constraints akan membuat perusahaan meningkatkan sumber pendanaan internal dengan penghematan kas melalui pengurangan biaya pajak. Perusahaan dalam kondisi financial constraints cenderung melakukan thin capitalization dalam rangka penghindaran pajak, namun cenderung tidak melakukan transfer pricing aggressiveness karena adanya risiko biaya tambahan yang akan dikeluarkan.

\section{REFERENSI}

Amidu, M., Coffie, W., \& Acquah, P. (2019). Transfer pricing, earnings management and tax avoidance of firms in Ghana. Journal of Financial Crime, 26(1). https://doi.org/10.1108/JFC-10-2017-0091

Andawiyah, A., Subeki, A., \& Hakiki, A. (2019). Pengaruh thin capitalization terhadap penghindaran pajak perusahaan index saham syariah Indonesia. Akuntabilitas, 13(1), 49-68. https://doi.org/10.29259/ja.v13i1.9342

Bandiyono, A., \& Murwaningsari, E. (2019). Effect of intra group transaction, thin capitalization and executive characters on tax avoidation with multinationality as a moderation. Journal of Accounting, Business and Finance Research, 7(2). https://doi.org/10.20448/2002.72.82.97

Bank Indonesia. (2009). Outlook Ekonomi Indonesia Krisis Finansial Global dan Dampaknya terhadap. Jakarta: $B I$.

Bastian, W. (2021, May 7). Resesi Ekonomi Masih Bercokol. Sindonews.Com. https://nasional.sindonews.com/read/420366/16/resesi-ekonomi-masih-bercokol1620295526

Chen, C., \& Lai, S. (2012). Financial constraint and tax aggressiveness. Working Paper, University of Auckland, 1-41.

Darma, S. S. (2019). Pengaruh related party transaction dan thin capitalization terhadap strategi penghindaran pajak. Jurnal Ilmiah Akuntansi Universitas Pamulang, 7(1). https://doi.org/10.32493/jiaup.v7i1.2204

Desai, M. A., \& Dharmapala, D. (2006). Corporate tax avoidance and high-powered incentives. Journal of Financial Economics, 79(1), 145-179. https://doi.org/10.1016/J.JFINECO.2005.02.002

DPR. (2014). Meningkatkan Tax Ratio Indonesia. 1-7. https://www.dpr.go.id/doksetjen/dokumen/apbn_Meningkatkan_Tax_Ratio_Indonesia20140 602100259.pdf

Dyreng, S. D., Hanlon, M., \& Maydew, E. L. (2010). The effects of executives on corporate tax avoidance. The Accounting Review, 85(4), 1163-1189. https://doi.org/10.2308/ACCR.2010.85.4.1163

Eden, L., \& Smith, L. M. (2011). The ethics of transfer pricing. AOS Workshop on "Fraud in Accounting, Organizations, and Society, " September 2009, 1-40.

Edwards, A. S., Schwab, C., \& Shevlin, T. (2013). Financial constraints and the incentive for tax planning. SSRN Electronic Journal. https://doi.org/10.2139/ssrn.2163766

Edwards, A. S., Schwab, C., \& Shevlin, T. (2016). Financial constraints and cash tax savings. Accounting Review, 91(3), 859-881. https://doi.org/10.2308/accr-51282

Falbo, T. D., \& Firmansyah, A. (2018). Thin capitalization, transfer pricing aggresiveness, penghindaran pajak. Indonesian Journal of Accounting and Governance, 2(1), 1-28. https://doi.org/10.36766/IJAG.V2I1.11

Fazzari, S., Hubbard, R. G., \& Petersen, B. C. (1988). Financing constraints and corporate investment. https://doi.org/10.3386/W2387

Firmansyah, A., \& Bayuaji, R. (2019). Financial constraints, investment opportunity set, financial 
reporting aggressiveness, tax aggressiveness: Evidence from indonesia manufacturing companies. Academy of Accounting and Financial Studies Journal, 23(5), 1-18.

Frank, M. margaret, Lynch, L. J., \& Rego, S. O. (2009). Tax reporting aggressiveness and its relation financial reporting University of Virginia. Accounting Review, 84(2), 467-496.

Ghozali, I. (2016). Aplikasi Analisis Multivariat dengan Program IBM SPSS 23. Badan Penebit Universitas Diponegoro.

Grubert, H., \& Mutti, J. (1991). Taxes, tariffs and transfer pricing in multinational corporate decision making. The Review of Economics and Statistics, 73(2), 285. https://doi.org/10.2307/2109519

Gujarati, D. N., \& Porter, D. C. (2012). Dasar-Dasar Ekonometrika (5th ed.). Salemba Empat.

Gusnardi. (2009). Penetapan harga transfer dalam kajian perpajakan. Pekbis Jurnal, 1(1), 36-43. https://pekbis.ejournal.unri.ac.id/index.php/JPEB/article/view/365/359

Hanlon, M., \& Heitzman, S. (2010). A review of tax research. Journal of Accounting and Economics, 50(2-3), 127-178. https://doi.org/10.1016/j.jacceco.2010.09.002

Hansen, D. R., \& Mowen, M. M. (2005). Managerial Accounting. Thomson Higher Education.

Horngren, C. T., Datar, S. M., \& Rajan, M. V. (2015). Cost Accounting: A Managerial Emphasis. Pearson Education.

Indah, R. B. P., \& Fitria, A. (2019). Kerikil tajam transfer pricing pada perusahaan multinasional serta dampak terhadap laporan keuangan. Jurnal Ilmu Dan Riset Akuntansi (JIRA), 8(10). http://jurnalmahasiswa.stiesia.ac.id/index.php/jira/article/view/2662

Jumailah, V. (2020). Pengaruh thin capitalization dan konservatisme akuntansi terhadap tax avoidance dengan kepemilikan institusional sebagai variabel moderasi. Management and Accounting Expose, 3(1), 13-21. https://doi.org/10.36441/MAE.V3I1.132

Koh, Y., \& Lee, H. A. (2015). The effect of financial factors on firms' financial and tax reporting decisions. Asian Review of Accounting, 23(2), 110-138. https://doi.org/10.1108/ARA-012014-0016

Kurniawan, A. M. (2015). Buku pintar transfer pricing untuk kepentingan pajak. ANDI. https://opac.perpusnas.go.id/DetailOpac.aspx?id=927421

Lim, Y. (2011). Tax avoidance, cost of debt and shareholder activism: Evidence from Korea. Journal of Banking and Finance, 35(2), 456-470. https://doi.org/10.1016/j.jbankfin.2010.08.021

Nadhifah, M., \& Arif, A. (2020). Transfer pricing, thin capitalization, financial distress, earning management, dan capital intensity terhadap tax avoidance dimoderasi oleh sales growth. Jurnal Magister Akuntansi Trisakti, 7(2), 145. https://doi.org/10.25105/jmat.v7i2.7731

Nainggolan, C., \& Sari, D. (2019). Kepentingan asing, aktivitas internasional, dan thin capitalization: Pengaruh terhadap agresivitas pajak di indonesia. Jurnal Akuntansi Dan Bisnis, 19(2), 147-159.

OECD. (2009). Countering Offshore Tax Evasion of the OECD Centre for Tax Policy and Administration Countering Offshore Tax Evasion: Some Questions and Answers. https://www.oecd.org/ctp/harmful/42469606.pdf

OECD. (2012). Thin Capitalization Legislation: A background paper for country tax administrators. 1-41.

Panjalusman, P. A., Nugraha, E., \& Setiawan, A. (2018). Pengaruh transfer pricing terhadap penghindaran pajak. Jurnal Pendidikan Akuntansi \& Keuangan, 6(2), 105. https://doi.org/10.17509/jpak.v6i2.15916

Prasetyowati, R. A. (2015). Capital structure choice: Macroeconomic conditions and financial constraints. Forthcoming Journal of Financial Economics, 10(1), 49-57. https://doi.org/10.32832/NERACA.V10I1.12

Rachmawati, N. A., \& Fitriana, A. (2021). The effect of financial constraints and institutional ownership on tax agressiveness. ACCRUALS (Accounting Research Journal of Sutaatmadja), 5(01), 38-53. https://doi.org/10.35310/accruals.v5i01.606

Richardson, G., \& Lanis, R. (2007). Determinants of the variability in corporate effective tax rates and tax reform: Evidence from Australia. Journal of Accounting and Public Policy, 26(6), 689-704. https://doi.org/10.1016/J.JACCPUBPOL.2007.10.003 
Richardson, G., Taylor, G., \& Lanis, R. (2013). Determinants of transfer pricing aggressiveness: Empirical evidence from Australian firms. Journal of Contemporary Accounting and Economics, 9(2), 136-150. https://doi.org/10.1016/j.jcae.2013.06.002

Richardson, S. (2006). Over-investment of free cash flow. Review of Accounting Studies, 11(2-3), 159-189. https://doi.org/10.1007/s11142-006-9012-1

Rosadi, F. (2019). Fenomena Tax Ratio Indonesia. Media Keuangan, XIV(138), 17-19.

Selistiaweni, S., Arieftiara, D., \& Samin, S. (2020). Pengaruh kepemilikan keluarga, financial distress dan thin capitalization terhadap penghindaran pajak. Prosiding BIEMA (Business Management, Economic, and Accounting National Seminar), 1(0), 751-763. https://conference.upnvj.ac.id/index.php/biema/article/view/925

Sugiono. (2004). Konsep, identifikasi, alat analisis dan masalah penggunaan variabel moderator. Jurnal Studi Manajemen Organisasi, 1(2), 61-70. https://doi.org/10.14710/jsmo.v1i2.4175

Taylor, G., \& Richardson, G. (2012). International corporate tax avoidance practices: Evidence from Australian firms. International Journal of Accounting, 47(4), 469-496. https://doi.org/10.1016/j.intacc.2012.10.004

Whited, T. M., \& Wu, G. (2006). Financial constraints risk. Review of Financial Studies, 19(2), 531-559. https://doi.org/10.1093/rfs/hhj012

Yorke, S. M., Amidu, M., \& Agyemin-Boateng, C. (2016). The effects of earnings management and corporate tax avoidance on firm value. International Journal of Management Practice, 9(2), 112-131. https://doi.org/10.1504/IJMP.2016.076741 